\title{
A direct conversion of benzylic and allylic alcohols to phosphonates
}

\author{
Rocky J. Barney, Rebekah M. Richardson, and David F. Wiemer ${ }^{\star}$ \\ Department of Chemistry University of lowa, lowa City, lowa 52242-1294
}

\begin{abstract}
Benzyl phosphonate esters often serve as reagents in Horner-Wadsworth-Emmons reactions. In most cases, they can be prepared from benzylic alcohols via formation of the corresponding halide followed by an Arbuzov reaction. To identify a more direct synthesis of phosphonate esters, we have developed a one-flask procedure for conversion of benzylic and allylic alcohols to the corresponding phosphonates through treatment with triethyl phosphite and $\mathrm{ZnI}_{2}$.
\end{abstract}

In recent years we have pursued the synthesis of a number of natural products that contain a trans-stilbene moiety, including the schweinfurthins ${ }^{1,2-6}$ (e.g. schweinfurthin $\mathrm{A},{ }^{1,6} \mathbf{1}$ ) and the pawhuskins ${ }^{7-9}$ (e.g. pawhuskin $\mathrm{C}^{7}{ }^{2}$ 2). The Horner-Wadsworth-Emmons condensation of a benzylic phosphonate with an aromatic aldehyde has proven to be a reliable strategy for formation of these trans-stilbenes. However, synthesis of the requisite phosphonate from the corresponding benzylic alcohol has relied upon a classic three-step protocol involving formation of the mesylate, conversion to the corresponding halide, and a final MichaelisArbuzov reaction. ${ }^{10,11}$ In some cases, this sequence has proven problematic ${ }^{12}$ or difficult to scale. Given our long-standing interest in carbon-phosphorus bond forming reactions, ${ }^{13-15}$ we were prompted to explore shorter paths to semi-stabilized phosphonates. We report here our results with a one-flask protocol based on treatment of the alcohol with triethyl phosphite in the presence of $\mathrm{ZnI}_{2}$.

It has been known for some time that alcohols which afford relatively stable cationic species, e. g. benzylic, allylic, and tertiary alcohols, can be activated with zinc halides. The resulting species have been trapped through reactions with hydride, ${ }^{16}$ alcohols, ${ }^{17}$ thiols, ${ }^{18}$ and other nucleophiles. ${ }^{19}$ However, somewhat to our surprise phosphorus nucleophiles have not been studied extensively in this type of reaction. ${ }^{20}$ Triethylphosphite also is a good nucleophile, and one might envision a parallel reaction that would afford a phosphonate product.

As an initial test case, benzyl alcohol (3) was treated with $\mathrm{ZnI}_{2}$ under a variety of conditions, and the reaction progress was assessed by inspection of the ${ }^{31} \mathrm{P}$ NMR spectrum of the reaction mixture. When the reaction was attempted at room temperature in toluene or methylene chloride, little or no product was detected. However, when the reaction was conducted at reflux in toluene, or even heated at $\sim 80{ }^{\circ} \mathrm{C}$, formation of the desired phosphonate $4^{21}$ was evident. After removal of the volatiles in vacuo, treatment of the residue with $\mathrm{NaOH}$ to remove $\mathrm{ZnO}, 22$ and column chromatography, phosphonate 4 was isolated in good yield (84\%).

david-wiemer@uiowa.edu.

Supporting Information Available: General experimental procedures, and the ${ }^{1} \mathrm{H}$ and ${ }^{13} \mathrm{C}$ NMR spectra for compounds 20, 25, 31, and $\mathbf{3 3}$ are presented. This material is available free of charge via the Internet at http://pubs.acs.org. 
To gauge the generality of this process, a number of benzylic alcohols were treated with triethyl phosphite and zinc iodide under parallel reaction conditions (Table 1). With 3-bromo and 3,4-dimethylbenzyl alcohols ( $\mathbf{5}$ and $\mathbf{7})$, the reactions proceeded smoothly and gave the expected phosphonates $\mathbf{6}^{23}$ and $\mathbf{8}^{24}$ in similar yields. With 4-methoxybenzyl alcohol (9), the yields were variable when the reaction was conducted in toluene, ranging from $76 \%$ (Trial 4) down to modest amounts, which may be due to competitive demethylation. ${ }^{25}$ However, when this reaction was conducted in THF at reflux (Trial 5), the desired phosphonate $\mathbf{1 0}^{26}$ was formed in good yield. Parallel results were observed with the nitro compound 11. The desired product $12^{27}$ could not be detected by ${ }^{31} \mathrm{P}$ NMR upon attempted reaction in toluene. In this case, reduction of the nitro group by the triethyl phosphite may be competitive at the high reaction temperature. ${ }^{28}$ When the reaction was conducted in THF, the desired phosphonate $\mathbf{1 2}$ was isolated in low yield (15\%). While the low yield may be a result of the electron withdrawing effect of the nitro group, it is more likely that nitrene formation is problematic even at the lower reaction temperature. This later view is supported by the results observed with the methoxycarbonyl compound 13. In this case, despite the presence of an electron withdrawing group, treatment with triethyl phosphite and zinc iodide under standard conditions resulted in C-P bond formation. These conditions also induced ester exchange to afford the ethyl ester $14 .^{29}$

Because natural products like the schweinfurthins and the pawhuskins often display phenols, application of this reaction to protected phenols was of special interest. With the di-MOM protected compound $\mathbf{1 5}$, the desired phosphonate $16^{30}$ was readily obtained although the yield was modest. In a similar sense, the di-TBS protected compound $\mathbf{1 7}$ could be converted to phosphonate $\mathbf{1 8},{ }^{31}$ although again the isolated yield was diminished relative to the reaction with benzyl alcohol itself (3). A more attractive yield was obtained with the benzofuran 19, suggesting that systems with a single protecting group may undergo this transformation more smoothly than those that bear two. ${ }^{25}$ Attempted preparation of phosphonate 20 via a traditional Arbuzov sequence led only to decomposition. ${ }^{12}$

Finally, zinc bromide also has proven to be effective for conversion of benzyl alcohol to phosphonate 4 (Trial 11). Although this yield was a bit lower than that observed with zinc iodide (Trial 1, Table 1) and a longer reaction time was employed, this is still an efficient transformation.

The generally attractive yields available with the benzylic alcohols summarized in Table 1 , encouraged exploration of this process with other alcohols that might afford relatively stable cationic systems. Several isoprenoid phosphonates have been studied as inhibitors of isoprenoid metabolism, 32 and so the first examples examined in this reaction were terpenoid allylic alcohols (Table 2). Geraniol (21) reacted smoothly under the standard reaction conditions to afford diethyl geranylphosphonate (22). ${ }^{33}$ In contrast, the tertiary allylic alcohol linalool (23) gave a complex mixture under the standard reaction conditions, although the geranyl phosphonate $\mathbf{2 2}$ could be isolated from this reaction in modest yield. Perillyl alcohol (24) and cinammyl alcohol (26) also reacted smoothly under the standard reactions conditions, and gave the expected phosphonates $\mathbf{2 5}^{34}$ and $\mathbf{2 7}^{35}$ in good yields. This suggests that a free carbocation is not formed and/or that steric factors dominate the site of C-P bond formation. In either case, it is clear that attack of the phosphorus nucleophile is consistantly favored at the primary position over the secondary or tertiary sites.

These results do not afford a complete mechanistic picture, but some aspects of the reaction sequence are apparent. While a process involving formation of an intermediate benzylic iodide and a subsequent Arbuzov reaction would explain formation of the phosphonate products, past work indicates that treatment of an alcohol with $\mathrm{ZnI}_{2}$ is more likely to afford the corresponding ether than the iodide. ${ }^{16,17,20 \mathrm{a}}$ Furthermore, no evidence for an 
intermediate iodide was found in this case. Addition of a substantial excess of $\mathrm{ZnI}_{2}$ was detrimental to isolated yields, contrary to what one might expect if formation of an intermediate iodide were required, and when sub-stoichiometric amounts of $\mathrm{ZnI}_{2}$ were employed, it became the limiting reagent. Formation of a zinc-phosphite complex may be more likely, a conclusion supported by a shift in the ${ }^{31} \mathrm{P}$ NMR resonance when $\mathrm{ZnI}_{2}$ is added to a solution of $(\mathrm{EtO})_{3} \mathrm{P}$ (from 138.6 to $33.6 \mathrm{ppm}$ ). A similar resonance was observed when the reaction mixture was analyzed by ${ }^{31} \mathrm{P}$ NMR.

Application of this protocol to $(S)-1$-phenyl-ethanol gave phosphonate that was essentially racemic by chiral HPLC analysis ( $\sim 3 \%$ ee), which suggests an $\mathrm{S}_{\mathrm{N}} 1$-like process. The tertiary alcohol 2-phenyl-2-propanol failed to react under these conditions, which may reflect the importance of steric effects as noted above with the allylic systems. Taken together, these factors lead to the partial mechanistic picture offered in Scheme 2. If formation of a tetracoordinate zinc species ${ }^{36}$ such as the complex $\mathbf{2 8}$ were followed by formation of a C-P bond through a process with $\mathrm{S}_{\mathrm{N}} 1$ character, the loss of stereochemistry could be explained. Formation of such a complex might be sensitive to steric factors in the original alcohol, which would be consistent with the lack of product from the tertiary alcohol. Finally, the last Arbuzov-like step on an intermediate such as $\mathbf{2 9}$ might be assisted by the presence of zinc halide serving as a Lewis acid, ${ }^{37}$ which would explain why a slight excess (1.1 to $1.5 \mathrm{eq}$ ) of the $\mathrm{ZnI}_{2}$ is beneficial.

While there is clear literature precedent ${ }^{16-19}$ for conversion of benzylic and allylic alcohols to other functionality through zinc halide mediated reactions, the common assumption is that such transformations are facile only in systems that afford stabilized cationic species.

Nevertheless, the simplicity of these reaction conditions and the attractive yields observed with many allylic and benzylic systems encouraged examination of a simple primary alcohol. Treatment of alcohol $\mathbf{3 0}$ with $\mathrm{ZnI}_{2}$ in toluene (Scheme 3) did afford a phosphonate product of the desired molecular weight, but the ${ }^{1} \mathrm{H}$ and ${ }^{13} \mathrm{C}$ NMR spectra of this material were not consistent with those expected for phosphonate 32. An authentic sample of phosphonate $\mathbf{3 2}^{38}$ was prepared in quantitative yield through catalytic hydrogenation of phosphonate $\mathbf{2 7}$ and was clearly a different compound. The structure of the $\mathrm{ZnI}_{2}$ mediated product was assigned as compound $\mathbf{3 1}$, based upon its spectral data. While the methylene groups of the two esters overlap in the ${ }^{1} \mathrm{H}$ NMR spectrum, the corresponding carbon resonances are distinct, which indicates the absence of symmetry around the central phosphorus. Furthermore, the presence of a methylene group directly bonded to phosphorus was apparent in a ${ }^{13} \mathrm{C}$ resonance at $18.3 \mathrm{ppm}\left(J_{\mathrm{CP}}=142 \mathrm{~Hz}\right)$.

A reaction sequence leading to phosphonate $\mathbf{3 1}$ might be based on a Lewis acid mediated ester exchange between the aliphatic alcohol and triethyl phosphite, followed by a more traditional Arbuzov reaction. When alcohol 30 was treated with $\mathrm{ZnI}_{2}$ in THF, phosphonate 31 was accompanied by ethyl 3-phenylpropyl phosphite (33) in a 1:1 ratio, which confirms that ester exchange can occur under these reaction conditions. Although the scope of this reaction with primary aliphatic alcohols has not yet been established, formation of phosphonate $\mathbf{3 1}$ does indicate the importance of a benzylic or allylic system for direct conversion of an alcohol to the corresponding phosphonate in the $\mathrm{ZnI}_{2}$ mediated reactions.

In summary, we have demonstrated that benzylic and allylic alcohols can be converted to the corresponding phosphonates through reactions with triethyl phosphite mediated by zinc iodide. This procedure provides a convenient alternative to the traditional Arbuzov reaction in these systems. Furthermore, because benzylic systems conjugated to electronwithdrawing substituents undergo this transformation in at least modest yields under these conditions, the reaction may be of broader utility. Studies designed to explore and extend the scope of this reaction will be reported in due course. 


\section{Experimental Section}

\section{General Experimental Procedure}

To a stirred solution of $\mathrm{ZnI}_{2}(1.5 \mathrm{eq})$ in anhydrous toluene or freshly distilled THF was added $\mathrm{P}(\mathrm{OEt})_{3}(1.5-3 \mathrm{eq})$ followed by the alcohol. The reaction mixture was allowed to stir at reflux overnight (approximately 12 hours). After it had cooled to room temperature, the reaction mixture was immediately placed on a vacuum line to remove volatiles. The residue then was washed with $2 \mathrm{~N} \mathrm{NaOH}$ until the solids dissolved, extracted with ether, dried $\left(\mathrm{MgSO}_{4}\right)$, and concentrated in vacuo. The resulting oil was purified via flash column chromatography on silica gel to afford the desired diethyl phosphonate.

\section{Diethyl (4-(tert-butyldimethylsilyloxy)benzo-furan-6-yl)methylphosphonate (20)}

Treatment of alcohol $19(60 \mathrm{mg}, 0.22 \mathrm{mmol})$ under standard conditions in toluene at reflux gave phosphonate $20(55 \mathrm{mg}, 64 \%)$ as a colorless oil after purification by column chromatography (33\% EtOAc in hexane). ${ }^{1} \mathrm{H}$ NMR $\left(400 \mathrm{MHz}, \mathrm{CDCl}_{3}\right) \delta 7.49(\mathrm{dd}, J=2.3$, $\left.J_{H P}=1.0 \mathrm{~Hz}, 1 \mathrm{H}\right), 7.09-7.08(\mathrm{~m}, 1 \mathrm{H}), 6.74\left(\mathrm{dd}, J=2.2, J_{H P}=0.8 \mathrm{~Hz}, 1 \mathrm{H}\right), 6.64\left(\mathrm{~d}, J_{H P}=\right.$ $2.25 \mathrm{~Hz}, 1 \mathrm{H}), 4.04-3.99(\mathrm{~m}, 4 \mathrm{H}), 3.20\left(\mathrm{~d}, J_{H P}=21.5 \mathrm{~Hz}, 2 \mathrm{H}\right), 1.25(\mathrm{t}, J=7.2 \mathrm{~Hz}, 6 \mathrm{H}), 1.04$ $(\mathrm{s}, 9 \mathrm{H}), 0.24(\mathrm{~s}, 6 \mathrm{H}) ;{ }^{13} \mathrm{C} \mathrm{NMR}\left(100 \mathrm{MHz}, \mathrm{CDCl}_{3}\right) \delta 156.5\left(\mathrm{~d}, J_{C P}=2.8 \mathrm{~Hz}\right), 148.9\left(\mathrm{~d}, J_{C P}\right.$ $=3.0 \mathrm{~Hz}), 143.6\left(\mathrm{~d}, J_{C P}=1.4 \mathrm{~Hz}\right), 128.5\left(\mathrm{~d}, J_{C P}=9.2 \mathrm{~Hz}\right), 119.5\left(\mathrm{~d}, J_{C P}=3.0 \mathrm{~Hz}\right), 114.3$ $\left(\mathrm{d}, J_{C P}=6.1 \mathrm{~Hz}\right), 106.4\left(\mathrm{~d}, J_{C P}=7.6 \mathrm{~Hz}\right), 104.1\left(\mathrm{~d}, J_{C P}=1.6 \mathrm{~Hz}\right), 62.1\left(\mathrm{~d}, J_{C P}=6.8 \mathrm{~Hz}\right.$, 2C), $33.9\left(\mathrm{~d}, J_{C P}=138.6 \mathrm{~Hz}\right), 25.6(3 \mathrm{C}), 18.2,16.4\left(\mathrm{~d}, J_{C P}=5.9 \mathrm{~Hz}, 2 \mathrm{C}\right),-4.4(2 \mathrm{C}) ;{ }^{31} \mathrm{P}$ NMR $\left(\mathrm{CDCl}_{3}\right) \delta$ 26.3. Anal. Calcd for $\mathrm{C}_{19} \mathrm{H}_{31} \mathrm{O}_{5} \mathrm{PSi}: \mathrm{C}, 57.26 ; \mathrm{H}, 7.84$. Found: $\mathrm{C}, 56.96 ; \mathrm{H}$, 8.02 .

\section{(S)-(p-Menth-1,8-dien-7-yl) phosphonic acid, diethyl ester (25)}

Treatment of alcohol $24(0.50 \mathrm{~g}, 3.28 \mathrm{mmol})$ under standard conditions in toluene at reflux gave phosphonate $25(0.70 \mathrm{~g}, 78 \%)$ as a colorless oil after purification by column chromatography (30\% to 50\% EtOAc in hexane). ${ }^{1} \mathrm{H} \mathrm{NMR}\left(300 \mathrm{MHz}, \mathrm{CDCl}_{3}\right) \delta 5.63$ (br s, $1 \mathrm{H}), 4.73-4.70(\mathrm{~m}, 2 \mathrm{H}), 4.15-4.05(\mathrm{~m}, 4 \mathrm{H}), 2.52\left(\mathrm{~d}, J_{H P}=21.8 \mathrm{~Hz}, 2 \mathrm{H}\right), 2.21-2.09(\mathrm{~m}, 4 \mathrm{H})$, 2.03-1.92 (m, 1H), 1.87-1.78 (m, 1H), $1.73(\mathrm{~s}, 3 \mathrm{H}), 1.55-1.42(\mathrm{~m}, 1 \mathrm{H}), 1.32(\mathrm{t}, J=7.1 \mathrm{~Hz}$, $6 \mathrm{H}) ;{ }^{13} \mathrm{C}$ NMR $\left(75 \mathrm{MHz}, \mathrm{CDCl}_{3}\right) \delta 149.5,127.9\left(\mathrm{~d}, J_{C P}=11.0 \mathrm{~Hz}\right), 125.8\left(\mathrm{~d}, J_{C P}=12.5\right.$ $\mathrm{Hz}), 108.5,61.6\left(\mathrm{~d}, J_{C P}=1.8 \mathrm{~Hz}\right), 61.5\left(\mathrm{~d}, J_{C P}=1.9 \mathrm{~Hz}\right), 40.3,34.8\left(\mathrm{~d}, J_{C P}=137.7 \mathrm{~Hz}\right)$, $30.7\left(\mathrm{~d}, J_{C P}=2.8 \mathrm{~Hz}\right), 29.7\left(\mathrm{~d}, J_{C P}=2.8 \mathrm{~Hz}\right), 27.6,20.6,16.3\left(\mathrm{~d}, J_{C P}=6.1 \mathrm{~Hz}, 2 \mathrm{C}\right) ;{ }^{31} \mathrm{P}$ NMR $\left(\mathrm{CDCl}_{3}\right) \delta$ 27.9; HRMS $\left(\mathrm{EI}^{+}\right)$calcd for $\mathrm{C}_{14} \mathrm{H}_{25} \mathrm{O}_{3} \mathrm{P}\left(\mathrm{M}^{+}\right)$272.1541; found: 272.1535 . Anal. Calcd for $\mathrm{C}_{14} \mathrm{H}_{25} \mathrm{O}_{3} \mathrm{P} \cdot \mathrm{H}_{2} \mathrm{O}: \mathrm{C}, 57.92 ; \mathrm{H}, 9.37$. Found: C, 57.89; H, 9.19.

\section{Ethyl (3-phenyl)propyl ethylphosphonate (31)}

Treatment of alcohol $30(0.50 \mathrm{~g}, 3.68 \mathrm{mmol})$ under standard conditions in toluene at reflux gave phosphonate 31 (469 mg, 50\%) as a colorless oil after purification by chromatography with EtOAc in hexane. ${ }^{1} \mathrm{H}$ NMR $(300 \mathrm{MHz}) \delta 7.30-7.23(\mathrm{~m}, 2 \mathrm{H}), 7.19-7.16(\mathrm{~m}, 3 \mathrm{H}), 4.14-$ $4.00(\mathrm{~m}, 4 \mathrm{H}), 2.71(\mathrm{t}, J=7.2 \mathrm{~Hz}, 2 \mathrm{H}), 2.03-1.92(\mathrm{~m}, 2 \mathrm{H}), 1.81-1.66(\mathrm{~m}, 2 \mathrm{H}), 1.31(\mathrm{t}, J=$ $6.6 \mathrm{~Hz}, 3 \mathrm{H}), 1.16\left(\mathrm{dt}, J_{H P}=19.8, J=7.8 \mathrm{~Hz}, 3 \mathrm{H}\right) ;{ }^{13} \mathrm{C} \mathrm{NMR}(75 \mathrm{MHz}) \delta 140.7,128.1(4 \mathrm{C})$, $125.6,64.1\left(\mathrm{~d}, J_{C P}=6.5 \mathrm{~Hz}\right), 61.1\left(\mathrm{~d}, J_{C P}=6.6 \mathrm{~Hz}\right), 31.8\left(\mathrm{~d}, J_{C P}=6.2 \mathrm{~Hz}\right), 31.4,18.3(\mathrm{~d}$, $\left.J_{C P}=141.5 \mathrm{~Hz}\right), 16.1\left(\mathrm{~d}, J_{C P}=5.9 \mathrm{~Hz}\right), 6.3\left(\mathrm{~d}, J_{C P}=6.8 \mathrm{~Hz}\right) ;{ }^{31} \mathrm{P} \mathrm{NMR}\left(\mathrm{CDCl}_{3}\right) \delta 33.7$; HRMS $\left(\mathrm{EI}^{+}\right)$calcd for $\mathrm{C}_{13} \mathrm{H}_{21} \mathrm{O}_{3} \mathrm{P}\left(\mathrm{M}^{+}\right)$256.1229; found: 256.1220 .

\section{Ethyl 3-phenylpropyl phosphite (33)}

Treatment of alcohol $\mathbf{3 0}(1.0 \mathrm{~g}, 7.35 \mathrm{mmol})$ under standard conditions in THF at reflux gave phosphonate $31(530 \mathrm{mg}, 28 \%)$ and phosphite $\mathbf{3 3}(478 \mathrm{mg}, 27 \%)$ as a colorless oil after purification by column chromatography (25\% to 50\% EtOAc in hexane). For compound 33: ${ }^{1} \mathrm{H}$ NMR $\delta 7.16(\mathrm{~d}, J=6.9 \mathrm{~Hz}, 2 \mathrm{H}), 7.09-7.03(\mathrm{~m}, 3 \mathrm{H}), 6.69\left(\mathrm{~d}, J_{H P}=693 \mathrm{~Hz}, 1 \mathrm{H}\right)$, 
4.08-3.91 (m, 4H), $2.61(\mathrm{t}, J=7.5 \mathrm{~Hz}, 2 \mathrm{H}), 1.94-1.84(\mathrm{~m}, 2 \mathrm{H}), 1.24(\mathrm{t}, J=6.9 \mathrm{~Hz}$, $3 \mathrm{H}) ;{ }^{13} \mathrm{C}$ NMR $\delta 140.3,128.0(2 \mathrm{C}), 127.9(2 \mathrm{C}), 125.7,64.3\left(\mathrm{~d}, J_{C P}=5.6 \mathrm{~Hz}\right), 61.4\left(\mathrm{~d}, J_{C P}\right.$ $=5.8 \mathrm{~Hz}), 31.5\left(\mathrm{~d}, J_{C P}=6.4 \mathrm{~Hz}\right), 31.1,15.9\left(\mathrm{~d}, J_{C P}=6.1 \mathrm{~Hz}\right) ;{ }^{31} \mathrm{P}$ NMR $\delta 7.6 ; \mathrm{HRMS}$ $\left(\mathrm{EI}^{+}, \mathrm{m} / z\right)$ calcd for $\left(\mathrm{M}^{+}\right) \mathrm{C}_{11} \mathrm{H}_{17} \mathrm{O}_{3} \mathrm{P}: 228.0915$; found: 228.0923 .

\section{Supplementary Material}

Refer to Web version on PubMed Central for supplementary material.

\section{Acknowledgments}

Financial support in the form of a University of Iowa Presidential Fellowship (to R. M. R.), and from the Roy J. Carver Charitable Trust and the National Institutes of Health (DA026573) is gratefully acknowledged.

\section{References}

1. a) Beutler JA, Shoemaker RH, Johnson T, Boyd MR. J Nat Prod. 1998; 61:1509-1512. [PubMed: 9868152] b) Beutler JA, Jato J, Cragg GM, Boyd MR. Nat Prod Lett. 2000; 14:399-404.c) Yoder BJ, Cao S, Norris A, Miller JS, Ratovoson F, Razafitsalama J, Andriantsiferana R, Rasamison VE, Kingston DGI. J Nat Prod. 2007; 70:342-346. [PubMed: 17326683] d) Thoison O, Hnawia E, Gueritte-Voegelein F, Sevenet T. Phytochemistry. 1992:1439-1442.

2. Treadwell EM, Cermak SC, Wiemer DF. J Org Chem. 1999; 64:8718-8723.

3. Neighbors JD, Beutler JA, Wiemer DF. J Org Chem. 2005; 70:925-931. [PubMed: 15675850]

4. Mente NR, Wiemer AJ, Neighbors JD, Beutler JA, Hohl RJ, Wiemer DF. Bioorg Med Chem Letters. 2007; 17:911-915.

5. Mente NR, Neighbors JD, Wiemer DF. J Org Chem. 2008; 73:7963-7970. [PubMed: 18795788]

6. a) Topczewski JJ, Neighbors JD, Wiemer DF. J Org Chem. 2009; 74:6965-6972. [PubMed: 19697910] b) Topczewski JJ, Kodet JG, Wiemer DF. J Org Chem. 2011; 76:909-919. [PubMed: 21226493]

7. Belofsky G, French AN, Wallace DR, Dodson SL. J Nat Prod. 2004; 67:26-30. [PubMed: 14738380]

8. Neighbors JD, Salnikova MS, Wiemer DF. Tetrahedron Lett. 2005; 46:1321-1324.

9. Neighbors JD, Buller MJ, Boss KD, Wiemer DF. J Nat Prod. 2008; 71:1949-1952. [PubMed: 18922035]

10. a) Maryanoff BE, Reitz AB. Chem Rev. 1989; 89:863-927.b) Bhattacharya AK, Thyagarajan G. Chem Rev. 1981; 81:415-430.

11. A number of other approaches to phosphonates and phosphonic acids are known. a) For phosphonate synthesis from o-(hydroxymethy1)phenols: Böhmer V, Vogt W, Chafaa S, Meullemeestre J, Schwing MJ, Vierling F. Helv Chim Acta. 1993; 76:139-149.For phosphonate synthesis via Pd-couplings: b) Lavén G, Stawinski J. Synlett. 2009:225-228.For synthesis of phosphonic acids from alcohols: c) Coudray L, Montchamp JL. Eur J Org Chem. 2008:41014103.d) Bravo-Altamirano K, Montchamp JL. Tetrahedron Lett. 2007; 48:5755-5759. [PubMed: 17940584]

12. Ulrich NC, Kodet JG, Mente NR, Kuder CH, Beutler JA, Hohl RJ, Wiemer DF. Bioorg Med Chem. 2010; 18:1676-1683. [PubMed: 20116262] b) Kodet, JG. PhD Thesis. University of Iowa; December. 2010

13. a) Hammond GB, Calogeropoulou T, Wiemer DF. Tetrahedron Lett. 1986; 27:4265-4268.b) Calogeropoulou T, Hammond GB, Wiemer DF. J Org Chem. 1987; 52:4185-4190.c) Baker TJ, Wiemer DF. J Org Chem. 1998; 63:2613-2618. [PubMed: 11672127]

14. a) Lee K, Wiemer DF. J Org Chem. 1991; 56:5556-5560.b) Du Y, Wiemer DF. J Org Chem. 2002; 67:5701-5708. [PubMed: 12153272]

15. Chen X, Wiemer AJ, Hohl RJ, Wiemer DF. J Org Chem. 2002; 67:9331-9339. [PubMed: 12492335]

16. Lau CK, Dufresne C, Belanger PC, Pietre S, Scheigetz J. J Org Chem. 1986; 51:3038-3043. 
17. Kim S, Chung KN, Yang S. J Org Chem. 1987; 52:3917-3919.

18. Guindon Y, Grenette R, Fortin R, Rokach J. J Org Chem. 1983; 48:1357-1359.

19. a) Gauthier JY, Bourdon F, Young RN. Tetrahedron Lett. 1986; 27:15-18.b) Clarembeau M, Krief A. Tetrahedron Lett. 1984; 25:3625-3628.

20. For an acid-catalyzed approach to a benzylic phosphonate through a quinoid type of intermediate: Mugrage B, Diefenbacher C, Somers J, Parker DT, Parker T. Tetrahedron Lett. 2000; 41:20472050.

21. Plabst M, Stock N, Bein T. Cryst Growth Des. 2009; 9:5049-5060.

22. Greenwood, NN.; Earnshaw, A. Chemistry of the Elements. Oxford: Butterworth-Heinemann; 1997. p. 1206p. 1209

23. Katz HE, Bent SF, Wilson WL, Schilling ML, Ungashe SB. J Am Chem Soc. 1994; 116:66316635.

24. Irngartinger H, Stadler B. Eur J Org Chem. 1998:605-626.

25. Zinc iodide cleavage of methyl ethers has been reported: a) Hanessian S, Guindon Y. Tetrahedron Lett. 1980; 21:2305-2308.b) Benedetti MOV, Monteagudo ES, Burton G. J Chem Research (S). 1990:248-249.

26. Khartulyari AS, Kapur M, Maier ME. Org Lett. 2006; 8:5833-5836. [PubMed: 17134284]

27. Ramos AM, Beckers EH, Offermans T, Meskers SCJ, Janssen RA. J Phys Chem A. 2004; 108:8201-8211.

28. Cadogan JIG, Cameron-Wood M, Mackie RK, Searle RJG. J Chem Soc. 1965; 4831-4837

29. Chaplais G, Le Bideau J, Leclercq D, Vioux A. Chem Mater. 2003; 15:1950-1956.

30. Lee HJ, Lee YR, Kim SH. Helv Chim Acta. 2009; 92:1404-1412.

31. Takaya Y, Terashima K, Ito J, He Y, Tateoka M, Yamaguchi N, Niwa M. Tetrahedron. 2005; 61:10285-10290.

32. a) Eummer JT, Gibbs BS, Zahn TJ, Sebolt-Leopold JS, Gibbs RA. Bioorg Med Chem. 1999; 7:241-250. [PubMed: 10218815] b) Cermak DM, Du Y, Wiemer DF. J Org Chem. 1999; 64:388393.

33. Blau NF, Wang TTS, Buess CM. J Chem Eng Data. 1970; 15:206-208.

34. For preparation of the di-t-butyl ester of perillyl phosphonate 25 , see reference $32 \mathrm{a}$.

35. Jacinta Drew J, Letellier M, Morand P, Szabos AG. J Org Chem. 1987; 52:4047-4052.

36. Sardarian AR, Shahsavari-Fard Z. Synth Commun. 2007; 37:289-295.

37. a) Renard P-T, Vayron P, Charles Mioskowski C. Org Lett. 2003; 5:1661-1664. [PubMed: 12735746] b) Renard P-T, Vayron P, Leclerc E, Valleix A, Charles Mioskowski C. Angew Chem Int Ed. 2003; 42:2389-2392.

38. Takahashi H, Inagaki S, Yoshii N, Gao F, Nishihara Y, Takagi K. J Org Chem. 2009; 74:27942797. [PubMed: 19267488] 


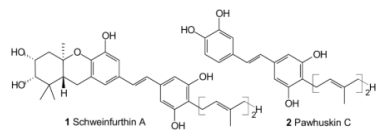

Figure 1.

Some isoprenylated trans-stilbene natural products. 


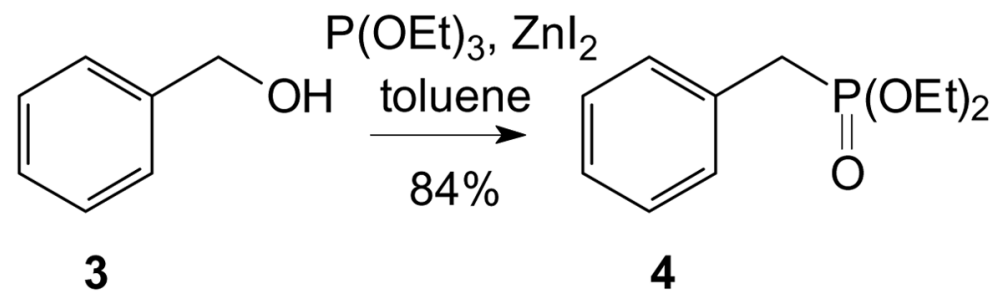

Scheme 1.

Conversion of benzyl alcohol to phosphonate 4 . 
$\left(\mathrm{CH}_{3} \mathrm{CH}_{2} \mathrm{O}\right)_{3} \mathrm{P}$

$\mathrm{ZnI}_{2}$

$\mathrm{HOCH}_{2} \mathrm{C}_{6} \mathrm{H}_{5}$

3

28

$\longrightarrow\left(\mathrm{CH}_{3} \mathrm{CH}_{2} \mathrm{O}\right)_{3} \mathrm{P}-\mathrm{Zn}$

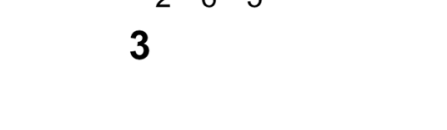

$\left(\mathrm{CH}_{3} \mathrm{CH}_{2} \mathrm{O}\right)_{2} \stackrel{\mathrm{O}}{\mathrm{P}} \mathrm{CH}_{2} \mathrm{C}_{6} \mathrm{H}_{5}$

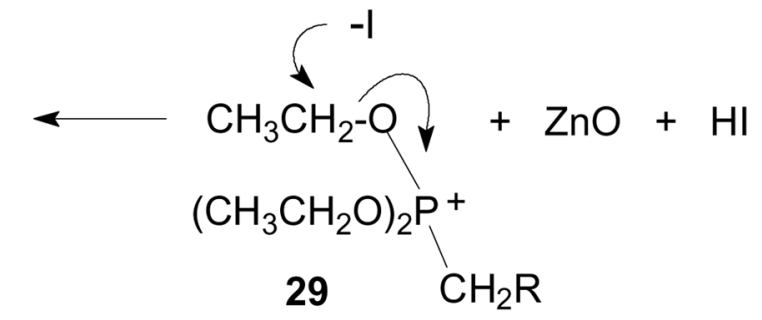

Scheme 2.

A partial mechanistic rationale. 
<smiles>CCOP(=O)(OCC)OCCCc1ccccc1</smiles>

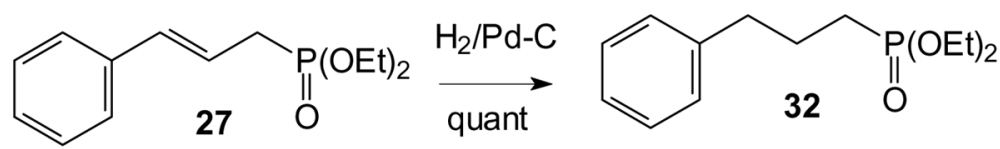

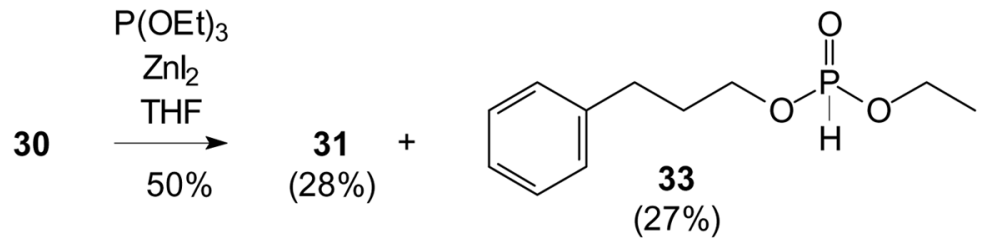

Scheme 3.

Synthesis of phosphonates $\mathbf{3 1}$ and $\mathbf{3 2}$. 


\section{Table 1}

Conversion of benzyl alcohols to diethyl benzylphosphonates in Zn-mediated reactions.

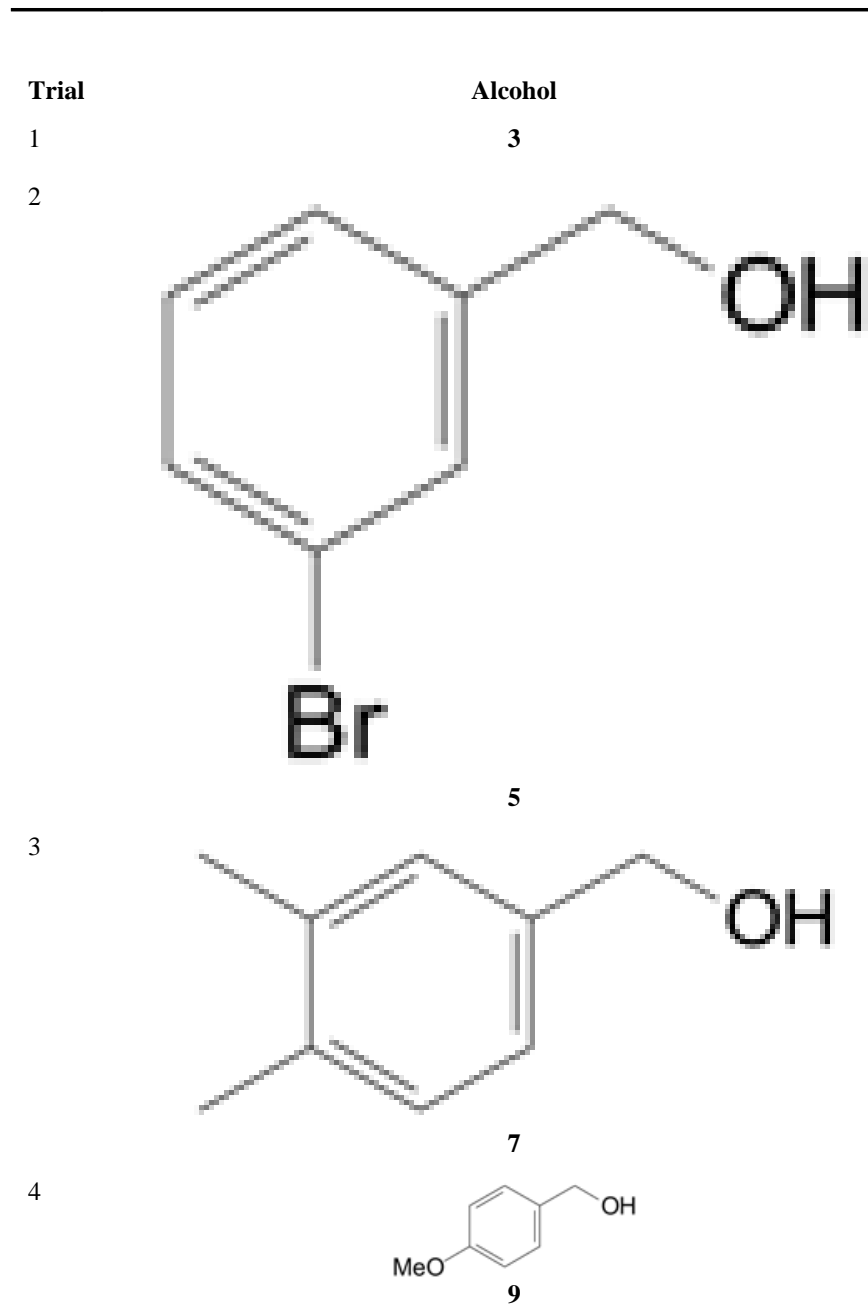

Phosphonate

4

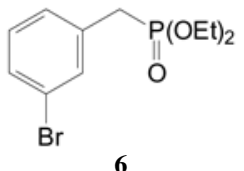

6

9

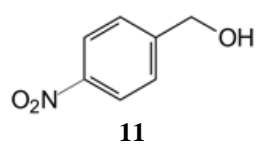

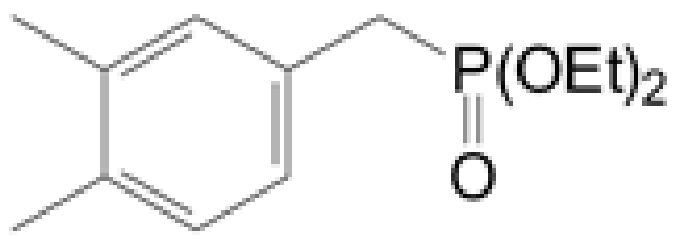

8<smiles>[O]c1ccc(CP=O)cc1</smiles>

$\mathrm{MeO}$

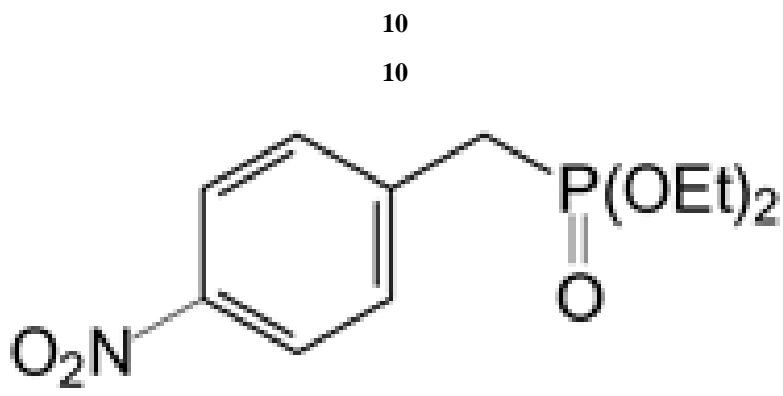



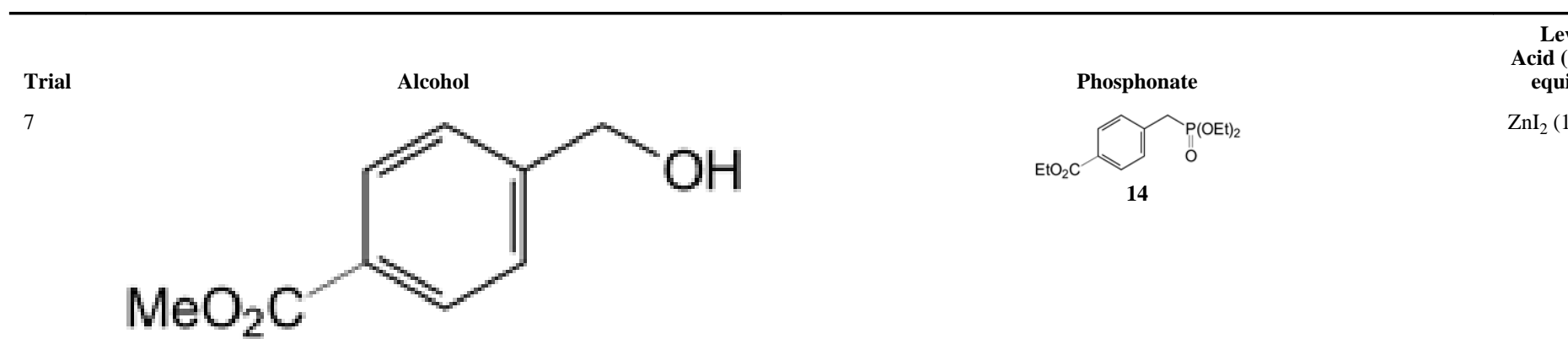

8
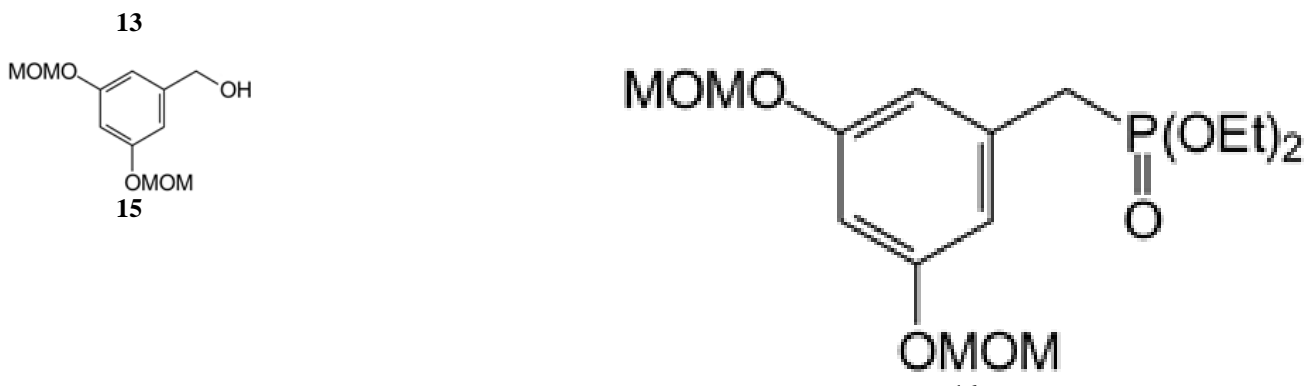

9
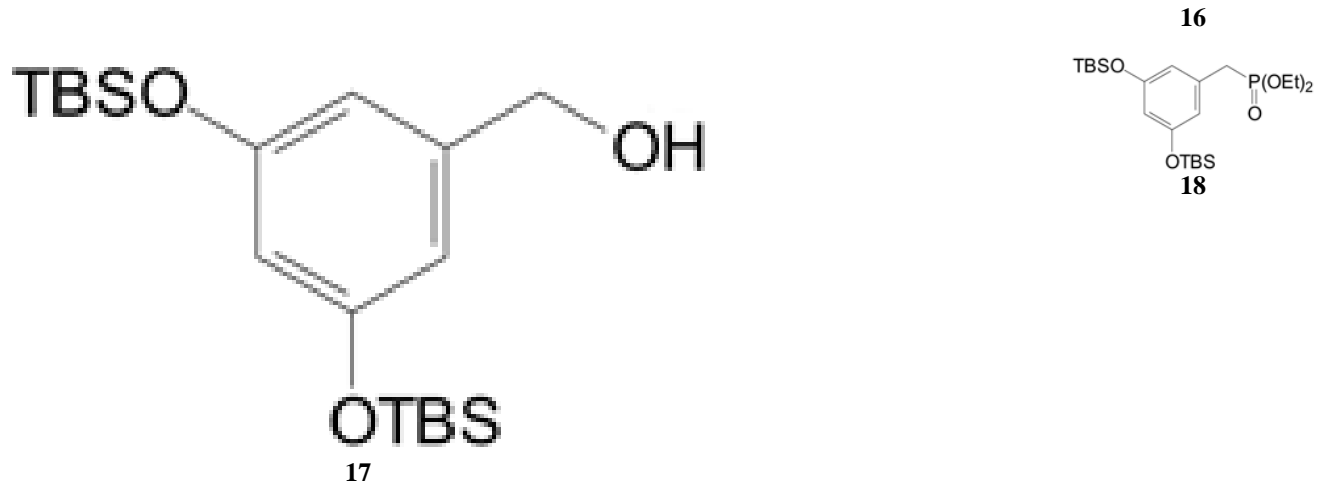

10

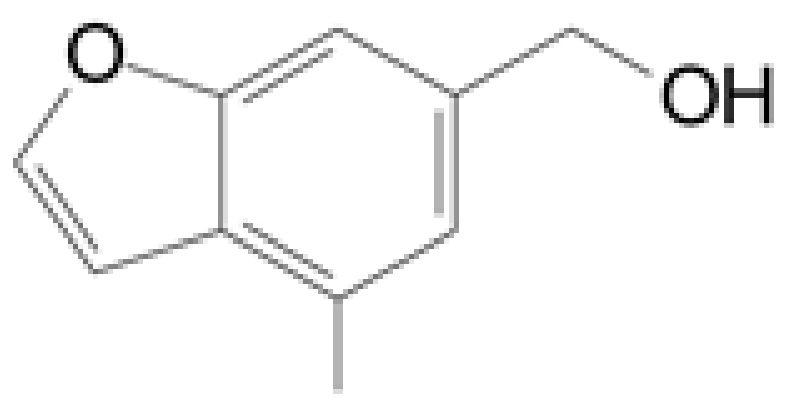

OTBS

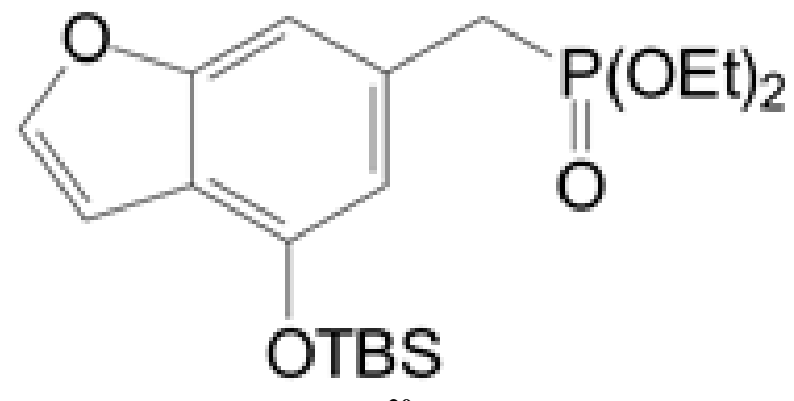

20

11

3

4

\footnotetext{
${ }^{a}$ Conducted at reflux in toluene.

${ }^{b}$ Conducted at reflux in THF.
} 
Table 2

Conversion of allylic alcohols to diethyl phosphonates in zinc-mediated reactions.

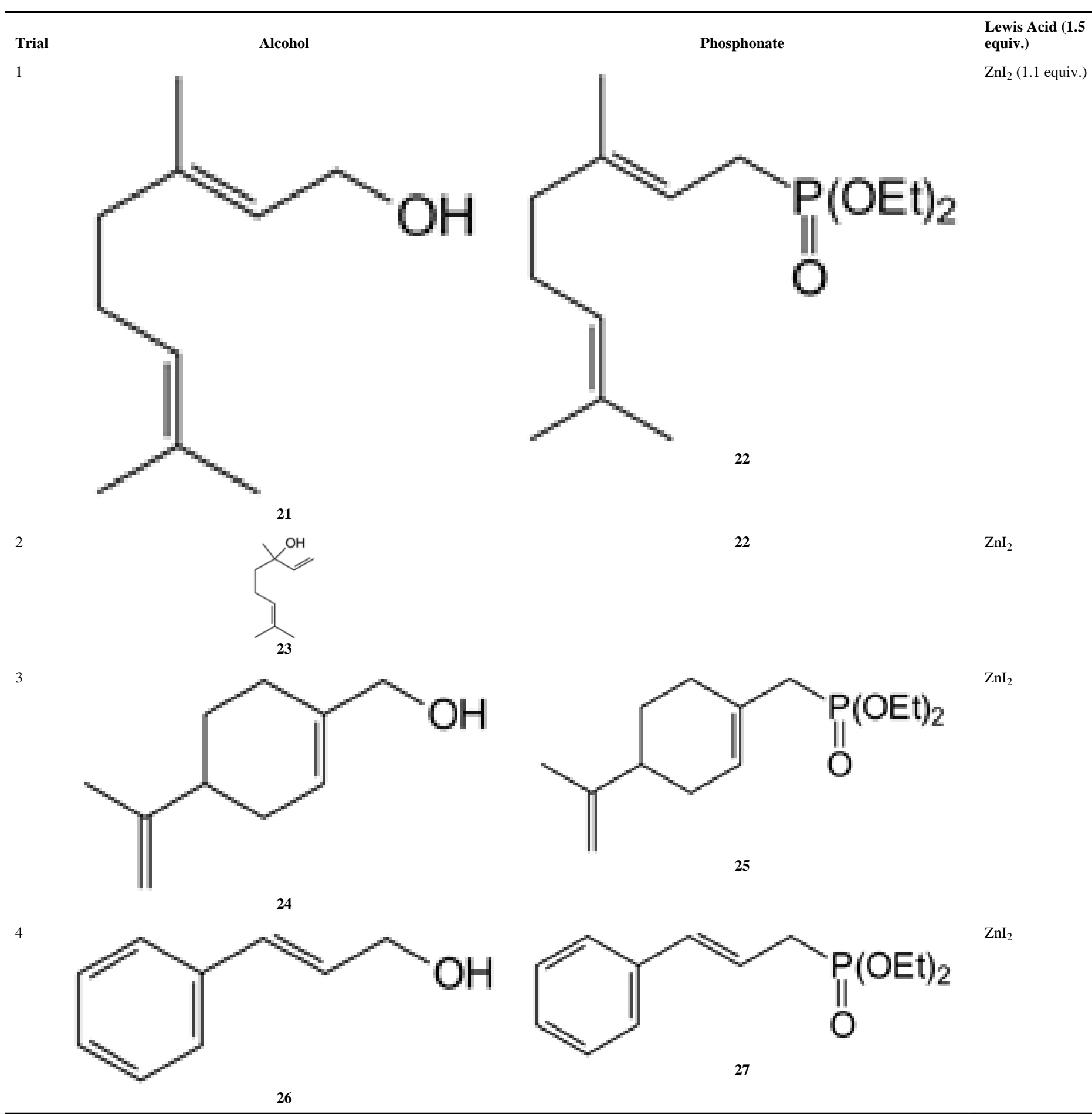

${ }^{a}$ Conducted at reflux in toluene. 
${ }^{b}$ Conducted at reflux in THF. 